\title{
Creating restoration landscapes: partnerships in large-scale conservation in the UK
}

\author{
$\underline{\text { William M. Adams }}^{1}, \underline{\text { Ian D. Hodge }}^{2}, \underline{\text { Nicholas A. Macgregor }}^{3,4}$ and Lindsey C. Sandbrook $^{1}$
}

\begin{abstract}
It is increasingly recognized that ecological restoration demands conservation action beyond the borders of existing protected areas. This requires the coordination of land uses and management over a larger area, usually with a range of partners, which presents novel institutional challenges for conservation planners. Interviews were undertaken with managers of a purposive sample of large-scale conservation areas in the UK. Interviews were open-ended and analyzed using standard qualitative methods. Results show a wide variety of organizations are involved in large-scale conservation projects, and that partnerships take time to create and demand resilience in the face of different organizational practices, staff turnover, and short-term funding. Successful partnerships with local communities depend on the establishment of trust and the availability of external funds to support conservation land uses. We conclude that there is no single institutional model for large-scale conservation: success depends on finding institutional strategies that secure long-term conservation outcomes, and ensure that conservation gains are not reversed when funding runs out, private owners change priorities, or land changes hands.
\end{abstract}

Key Words: biodiversity conservation; conservation governance; ecological restoration; landscape-scale conservation; neoliberalism; partnership

\section{INTRODUCTION}

The persistence of declines in biodiversity has stimulated demands for "alternative models for biodiversity conservation" (Radford 2014:2). Among new approaches proposed, three have attracted particular attention. First, increasing importance has been given to ecological restoration, now recognized in the Convention on Biological Diversity's Aichi Targets (CBD 2010) and the 2020 Biodiversity Strategy of the EU (Lammerant et al. 2013). Second, there has been a growing recognition that the creation of protected areas is no longer the sole responsibility of the state: nonstate actors, both private landowners and nongovernmental conservation organizations and trusts, have become increasingly important (Hodge and Adams 2012). Third, a consensus has emerged around the need to "scale up" conservation action and secure larger areas for wildlife protection. Thus, Fitzsimons and Wescott (2005:75) argue that "to maintain current levels of biodiversity, it is widely recognized that conservation efforts cannot be constrained to the public reserve system and that a landscape-scale approach to management is required across all land tenures."

This reflects research on habitat fragmentation and landscape connectivity (e.g., Crooks and Sanjayan 2006), and a growing consensus on the need to create bigger and more connected conservation areas (e.g., Mansergh et al. 2008), particularly in the light of anthropogenic climate change (Vos et al. 2008, Heller and Zavaleta 2009). Conservation organizations currently managing individual protected areas in isolation should therefore start to "plan their activities cooperatively on a regional scale" (Armsworth et al. 2015:165).

However, while there is some consensus among ecologists on the desirability of large-scale conservation, the institutional model to support this is less clearly established. Coordination of land uses and management over large areas often requires cooperation or partnership among state and nongovernmental conservation organizations, communities, and private landowners and managers (Adams et al. 2014). This presents novel challenges.

Large-scale conservation or restoration initiatives are variously referred to as "broad-extent conservation programmes" (Beever et al. 2014), "multi-tenure reserve networks" (Fitzsimons and Wescott 2007), large-scale conservation networks (Fitzsimons et al. 2013), "large-scale conservation areas" (Macgregor et al. 2012), or more generally as "landscape-scale conservation" (England Biodiversity Group 2011). We refer to all such initiatives using the term "large-scale conservation areas" (LSCAs).

We consider the challenges of establishing and managing LSCAs, drawing on a survey of initiatives in the UK. In the UK, Lawton et al. (2010) proposed establishment of an ecological network and associated Ecological Restoration Zones, and the government announced a new approach to biodiversity conservation focused on ecological restoration, conservation at a larger "landscape" scale (defined as "action that covers a large spatial scale, usually addressing a range of ecosystem processes, conservation objectives and land uses" [Defra 2011:18]), and a renewed engagement of private landowners (Adams et al. 2014). In 2012, 12 Nature Improvement Areas were announced in England, which were partnerships of conservation organizations, local authorities, local communities, and landowners (Adams et al. 2014). All major conservation NGOs have also established largescale conservation programs, mostly designed around their existing landholdings, including the National Trust, the Royal Society for the Protection of Birds ("Futurescapes"), and the Wildlife Trusts ("Living Landscapes" [Adams et al. 2014]).

\section{THE INSTITUTIONAL CHALLENGE OF LARGE-SCALE CONSERVATION}

In a neoliberal era, conservation based on land purchase and regulation by government has been progressively supplemented by more plural strategies, including private protected areas

\footnotetext{
${ }^{1}$ Department of Geography, University of Cambridge, Cambridge, UK, ${ }^{2}$ Department of Land Economy, University of Cambridge, Cambridge, UK, ${ }^{3}$ Natural England, Nobel House, London, UK, ${ }^{4}$ Durrell Institute of Conservation and Ecology (DICE), School of Anthropology and Conservation, University of Kent, Canterbury, Kent, UK
} 
(Hodge and Adams 2012, Stolton et al. 2014). Hybrid governance, blending public and private interests and institutions, is promised to combine the benefits of "small government" with the empowerment of local communities (McCarthy 2005, Lockie and Higgins 2007). The result is "institutional blending" (Hodge and Adams 2012), in which state and private actors interact in novel forms of governance. This mixes property regimes and different categories of ownership, the disaggregation and separate allocation of property rights (e.g., rights of access, to cultivate, to develop), the development of incentives for conservation management, and informal arrangements for governance and partnerships. This is supported through novel patterns of state regulation and payments (Hodge and Adams 2012).

The creation of LSCAs is therefore essentially a collective action problem(Ostrom 1990, 2005), characteristic of the management of complex environmental resources (Hodge 2016), and engaging with multiple owners and stakeholders from public and private sectors. LSCAs therefore demand some element of comanagement (Berkes 2009), where the processes of governance are shared among a group of stakeholders from government, private organizations, and civil society. Emerson et al. (2012) propose an integrative framework for collaborative governance, involving three elements: first, a process of "principled engagement," in which actors with different goals work across institutional, sectoral, or jurisdictional boundaries; second, shared motivation (a self-reinforcing cycle of mutual trust, understanding, internal legitimacy, and commitment); third, joint action to achieve outcomes unreachable without collaboration.

In the UK, some initiatives to promote collective management of land-based resources arise through specific government programs (e.g., River Basin District Liaison Panels [Cook et al. 2012]), or institutions for integrated catchment management (Short 2015), while others represent more ad hoc groupings (Benson et al. 2013). Both approaches have been used to create LSCAs, with various kinds of partnerships among state, private sector, and nongovernmental organizations. The common aim of such comanagement is to bring a range of resources and capabilities together at a local level to achieve social objectives. Advantages of the approach include access to the skills and specialisms of different organizations and individuals and their networks, to different resources (e.g., administrative capability), and to larger and more diverse areas of land, and the opportunity to share risks (Carlsson and Berkes 2005).

In the UK, LSCA projects take several forms. Some are single large landholdings, effectively standing alone as protected areas. Examples include private estates - for example, the private Knepp Estate (Sussex, England) - or a number of estates in Scotland (e.g., Rothiemurchus, Glenfeshie, Corrour), where the owner (often a family trust) has made a commitment to conservation. Conservation NGOs have acquired many large properties; for example, the National Trust (e.g., the Wicken Vision Area in England), the Royal Society for the Protection of Birds (RSPB) (e.g., reserves at Abernethy or Forsinard Flows in Scotland), the National Trust for Scotland (e.g., Mar Lodge, or the Isle of Canna), or the John Muir Trust (e.g., Sandwood
Bay, Scotland). In these cases, the "partnerships" involve primarily neighbors, funders, and scientific and government organizations.

Several LSCA partnerships include multiple ownerships. Two kinds exist in the UK. The first involves collaboration between partners who contribute their own properties; for example, Wild Ennerdale in Cumbria (Browning and Yannik 2004), a collaboration between an NGO (the National Trust), a government agency (Forestry Commission), and a private water company (United Utilities). Some such collaborations can involve larger numbers of partners; for example, the Coigach and Assynt Living Landscape in northwest Scotland, which was formed by four NGOs or trusts (the Scottish Wildlife Trust and John Muir Trust, Assynt Foundation, and Culag Community Woodland Trust) and three private landowners (Adams 2012). The second kind of multipartner LSCA involves a specific area or zone with large numbers of landowners whom the initiative seeks to engage in conservation activity. The NGO-led Wildlife Trust Living Landscapes and RSPB Futurescapes are this kind of LSCA.

LSCA partnerships are predominantly established informally, often by conservation NGOs. Without statutory authority or powers, these projects aim to influence land management within identified areas toward a wider social interest. Some LSCA initiatives involve collaborations between conservation landowners (governmental, nongovernmental, or private). Such conservation organizations might be expected to collaborate readily, although in fact, coordination of action between conservation organizations is not necessarily simple, even if they have similar goals.

In industrialized countries (especially in western Europe), rural land is mostly privately owned and often intensively farmed. Here, the success of LSCAs depends on persuading a sufficient number of private owners to change their management to favor conservation. The number of owners involved depends both on the scale of the initiative and on ecology. In the UK, hill and moorland areas tend to be in larger land units, managed extensively for shooting, grazing, or forestry. By contrast, in lowland areas, holdings tend to be smaller and land use is dominated by intensive agriculture. Here, the delivery of LSCAs demands coordination of independent land managers (c.f. Pasquini et al. 2011, Lacher and Wilkinson 2013). For these owners, conservation is not necessarily a major interest, and partnerships may need to address fundamental differences in motivation (Emerson et al. 2012).

\section{METHODS}

To explore the establishment, activities, and challenges of LSCAs, we interviewed 27 people in leadership positions in a large-scale initiative in the UK, between January and September 2012. Interviewees had various management or coordinating roles, and are referred to here generically as "managers." Initiatives were selected from a database of 800 large-scale conservation initiatives in England, Wales, and Scotland, compiled by Southampton University (Macgregor et al. 2012, Eigenbrod et al., in press). These initiatives were stratified on the basis of size $\left(10-49 \mathrm{~km}^{2}\right.$, $50-990 \mathrm{~km}^{2}$, and $>1000 \mathrm{~km}^{2}$ ) and number of landholders (10 or fewer, or more than 10). Within these categories, initiatives were selected purposively, taking account of geographical diversity (the 
range of environments across the UK), nature of lead organization (government and nongovernment), and logistics (time and travel costs). The final sample of 27 was made up of 16 initiatives in England, eight in Scotland, and three in Wales.

Managers of selected initiatives were contacted by telephone or email. Most interviews were conducted face-to-face $(n=23)$, the rest by phone or Skype $(n=4)$. We conducted indepth interviews using a common schedule of questions that explored the three elements identified by Emerson et al. (2012), devised in collaboration with a panel of researchers and practitioners involved in related research (Eigenbrod et al., in press). The approach was inductive, and looked for common approaches and challenges across the sample cases. Questions included contextual information (objectives and design of the project, the ecological factors driving its design, and sources of information) and focused on the institutions and practices of collaborative governance (the creation and maintenance of partnerships, arrangements, decision-making, conflict resolution, relations with landowners). Questions were open-ended and shared with interviewees before the interview. An attempt was made to create a rapport with the interviewees, so they could use their own words to clarify and explain complex issues and include topics not in the original list. By agreement, all interviews were recorded and transcribed verbatim. Interviews were transcribed, and coded using Atlas.ti to identify and group passages on a common theme, and then themes across interviews were linked. All quotes are anonymous, and are identified by a unique code number. Where organizations were named by respondents, an arbitrary set of initials is used in the text (e.g., organization XXX or YYY); these initials are not specific to any given organization. All information on named initiatives in this paper was derived from published or Web-based sources.

\section{RESULTS}

\section{Diversity of partnerships}

A number of different kinds of organization were involved in the initiatives surveyed, including individual landowners (from small farms up to large estates), charities, trusts, nongovernmental organizations, clubs, research institutions, national conservation agencies, utilities, and private companies (e.g., mining companies; ports; railway, water, and energy companies).

Interviewees used the term "partner" in three distinct ways. They distinguished between (i) "project partners," meaning close collaborators involved in the management of the initiative; (ii) "community partners," referring to landholders in the initiative area whose collaboration (especially in land management decisions) was essential to conservation outcomes; and (iii) "institutional partners," meaning broader stakeholders who could bring other resources, such as funding, scientific expertise, or administrative capacity. We focus primarily on the first two.

\section{Creating partnerships}

The creation of partnerships requires a high degree of pragmatism from different actors: interviewees emphasized the need to be realistic about what partnerships could achieve ("it's about making partnerships that make sense instead of partnerships for the sake of a partnership" [Interview 12]), and that it took time to establish effective multipartner initiatives, to build trust between organizations and individuals. It was clear that it took constant attention to move from trust to coordinated joint action (c.f. Emerson et al. 2012). One manager said of a funding bid, "after I submitted the application, I found out that [organization $\mathrm{XXX}]$ had submitted an application for doing virtually the same thing about five miles away... when [the funder] saw this they said, 'Oh: not working in partnership; bunch of clowns!'” (Interview $6)$.

The idea of large-scale conservation could provide the catalyst to combine previously separate nature reserves into one program, and to move passive cooperation into active collaboration. Projects were often built around pre-existing initiatives. One manager said, "The wider partnership project, as opposed to just the [organization's]... started in 2005 by the landowners, kind of completely separately...there was [another organization's] project as well, that started before the landowners' one and that's been amalgamated" (Interview 11).

Partnerships brought diverse strengths (c.f. Carlsson and Berkes 2005): "You know, [organization XXX] are obviously interested in ancient trees and native woodland, [organization YYY] are getting that way, they may be a bit more recreational now but with a commercial side as well... and then [organization $\mathrm{ZZZ}$ ] are all for the habitat and the bird life and everything so...It's great having all three" (Interview 25). Larger projects were seen by some managers as providing more security (more organizations to find financial resources or solve other problems, for example). However, some respondents thought that in larger partnerships, relatively less got achieved.

\section{Sustaining partnerships}

Having set up an LSCA partnership, the challenge is to sustain it. Many initiatives had a single "lead partner" that led decisionmaking. Often this went with financial responsibility for a grant that enabled project work to be done. One manager commented, "Yeah. I think it's safe to say that we are the people with the money... at the moment" [Interview 27]. Sometimes individual organizations retain decision-making powers over zones within a wider project that they previously controlled: "it is us leading, and it's us saying 'this is what we're going to do,' and that's fine" (Interview 11). Other managers wished to avoid taking a dominant role: "We're trying to make it less of a dominant partnership" (Interview 22).

However, relationships among partners can be problematic. Different working arrangements, for example over accounting, can create tensions. One initiative manager noted that "charities are allowed to claim full cost recovery on costs for staff. Public sector partners are not allowed to claim any staff time at all" (Interview 21), which makes it difficult to compare work done by different partners. It is not always easy to get along: one manager said, "[organization XXX] have been a very, very difficult organization to engage with. Their organizational structure is impenetrable. You don't understand who reports to who, how the departments fit together, the language they use is awful" (Interview 6). Relations are not always harmonious: one respondent said, "we've had our fingers slightly burnt with [organization YYY] because they did take the work that was done... and almost hold it up as a [project of their own]... But then you don't want to end up in the position that you completely burn your bridges..." (Interview 1). Another respondent commented simply, with respect to other partners, "we're careful about what we say" (Interview 11). 


\section{Formal structures}

There was variation in the degree to which initiatives involved formal agreements to tie partners together. Many initiatives had started informally. One manager said, "So all the project site owners, we got them to say, 'yes, we support this project,' without, you know, committing themselves...it's word of mouth rather than a formal agreement" (Interview 4).

Some partnerships remained informal (one respondent said, "we're not technically a partnership because we don't have a bank account and, you know, all that sort of stuff... we used to call it a partnership but I now call it a project" [Interview 25]). Other initiatives had some kind of informal written agreement: "I wouldn't say it's quite formalized, it's a page and a half of A4...It was a case of...having the document in place to bring the three partners together...Again, that took time...I think about a year and a half in total" (Interview 9). One initiative had a master plan ("a massive document") that "no one has formally signed up to, but everyone has pretty much....agreed that this is the direction that we want the project to go in" (Interview 11). The same project had an "officially agreed publicity statement" and "an official project partner logo": the manager commented, "that's, sort of, as formal as it gets" (Interview 11).

Some found that a legal agreement eventually became necessary to commit partners financially: one manager said, "I think probably the project got to the point where commitment had to be expressed in financial terms" (Interview 8). Formal arrangements often resulted from the demands of funding bodies. "What [organization XXX] require is that each organization who becomes a partner, there is a partnership agreement and that must be signed off at senior management level within the organizations, so that there is high level commitment at a corporate level from the partners" (Interview 21).

\section{Promoting resilience}

Partnership arrangements need constant attention, as circumstances or the priorities of partner organizations change, in a process of adaptive comanagement (Armitage et al. 2009). Learning from social-ecological feedback in the project area, or responses to changes of staff in partner organizations, demand a dynamic approach to partnerships. Processes of review differed in formality and extent. One interviewee commented, "We are intending to refresh and update that memorandum; we just haven't got around to it yet" (Interview 7). Some initiatives reviewed partners at intervals. One did so every two or three years, asking, "Who are the stakeholders, the people who are interested in what we're doing? When did we last engage with them? Have people within those groups changed?... Do we need to re-engage with that group to make sure that [a] senior manager or [a] particularly influential person is up to speed on what we're doing?" (Interview 9). Some initiatives do achieve periods of stability: "We had a project Steering Group... and we would go back to them every year and check. But I think it's fair to say that the Steering Group was quite involved in the early stages, and then backed off and were happy to leave us to get on with it [in a three-year project]..." [Interview 2]. But there will need to be more intensive activity in order to renew the funding and re-establish the partnership for a further period.

Restructuring demands flexibility. One respondent commented, "the biggest threat to [the initiative] is organizational change, and one of the partners being transformed into something else" (Interview 9). Many initiatives had changed over time, and with them the composition of the partnership. For example, one respondent described how an existing partnership was reformed in order to make an Nature Improvement Area bid: "With the new structure they are putting into place, I imagine we will be one of the actual partners in this bigger partnership. But [organization $\mathrm{XXX}$ ], they sort of take charge of that partnership... direct and oversee decisions made" (Interview 3).

The biggest driver of change in partnerships was lack of continuity in funding, described by one respondent as "the big stumbling block" (Interview 26). While one might expect LSCAs to be planned as long-term projects, in practice few could look ahead more than a few years. This is an example of "projectification," where policy initiatives have to be developed rapidly and with limited time horizons, thereby demanding great adaptability (Sjöblom and Godenhjelm 2009, Sjöblom et al. 2013). Everywhere, LSCAs were supported by short-term funding. Follow-on funds, to support a successful initiative, were often not available. One respondent commented, "With [landscape-scale projects], people fund them, and then they say, 'fantastic, it's a great success - we can never fund it again. You've shown what works, now we can't pay for that, you have to do something different"(Interview 2). As a result, projects sometimes just stopped: "unfortunately, that was just before everything went...wrong with the world, just because funding was drying up" (Interview 28). And with funding goes job security for key staff. One respondent commented, "I mean, if we get this Heritage Lottery Fund my post continues for a period of time as well, but if it doesn't..." (Interview 25).

Many initiatives obtain funds from agri-environment schemes or other general countryside grant schemes. The short-term nature of project funding is a problem here too because conservation outcomes cannot be switched on and off: "if you want the outcomes, you need a relationship both with individual landowners and with the landowning community, and that happens over decades" (Interview 6).

\section{Community partners}

Given the requirement for a long-term commitment, relationships with local communities, and especially landowners, are critical. Metcalf et al. (2015) note the importance of trust in restoration projects, but also that at a large-scale, trust is both more important and more difficult to develop. It is therefore critical to engage those who have direct control over the land - generally the local farmers: "it's about finding the influential farmers, and talking to them and getting them on our side, or at least willing to talk about it and using that as a network" (Interview 12). This is, however, often not easy: "It's quite easy to get to people that are interested... it's the farmers that... have slightly less interest... how do you engage with them?" (Interview 12).

Trust takes time to develop, but landowners can become frustrated with slow decision-making and the long-term nature of ecological outcomes (Metcalf et al. 2015). Moreover, the long-term aims of an initiative may not match the plans of local landowners and organizations who are asked to commit their land and resources or their thinking about future uncertainty.

In the UK, efforts in LSCAs often focus on persuading farmers to enter an agri-environment scheme: "quite a lot of the work is 
to do with supporting farmers getting into agri-environment schemes and then helping them to...optimize their work within agri-environment agreements" [Interview 7]. Another respondent said, "So, obviously, if we're trying to influence conservation on a landscape scale in these other areas, our only hook that we have or our only tool is SRDP [Scottish Rural Development Programme, which includes government agri-environment schemes]" (Interview 26).

But it may not be straightforward to make the links between landowner and funding scheme. Such schemes tend to be bureaucratic, with complex and intimidating forms for each landowner to complete. Thus, one manager said of the Scottish Rural Development Programme, simply, "well, SRDP is a real minefield..." (Interview 26). Another noted that the smallholdings on which areas of conservation interest occurred were not well served by the SRDP, not scoring enough "points" to win funding: "they fall between two stools in fact; they're not classed as woodland and they're not classed as agriculture and grazing" (Interview 21).

Beever et al. (2014) note that LSCA projects often have aims that extend well beyond just biodiversity. Attempts to engage with the broader needs and interests of local communities have led some large-scale initiatives in surprising directions: one became involved in the development of a microhydro project; the manager hoped it would "bring in some long-term revenue to put back into the core project" (Interview 27). Such diversification can potentially be a distraction for project staff. One respondent commented, "So, we've just produced an education resource for secondary schools which is linked to the curriculum for excellence, so that's...that's me going out. We produced a DVD... and we're just putting a web site together. So, all those sorts of things, totally fall on my shoulders" (Interview 25).

\section{DISCUSSION}

The shift toward large-scale conservation represents a significant reterritorialization of the conservation landscape (Adams et al. 2014), and involves a major role for private landowners and NGOs. This may be seen in the wider context of neoliberalization, which creates "multiple sites of governing" and "decenters the state as the seat of power: power bleeds across the social body in such a way that governing occurs in multiple sites and through a myriad of techniques" (Rutherford 2007:291). It offers new mechanisms for conservation but also creates new risks and challenges. Large-scale conservation demands institutional architectures that blend governmental and private tenure and management, thus creating hybrid institutions, and evolving partnerships between state and nonstate actors.

The creation of LSCAs involves establishing a vision that reflects and responds to stakeholder goals and values. It needs social entrepreneurship in order to engage with potential partners who can provide the land, resources, and skills, and to gain their commitment and motivation toward these wider ambitions, and to persuade them to implement changes in land use over sustained periods of time that will bring about desired outcomes. These are roles not always easily undertaken by government. But the largescale conservation movement is in a relatively early stage in its development. It has opened up significant potential and had some success at the level of individual initiatives (Ellis et al. 2012) but has yet to deliver widespread, well-documented, and sustainable conservation outcomes.
The creation and operation of successful large-scale partnerships, like other forms of comanagement, demand substantial and continuing commitment of time and resources. The cost of restoration and conservation is often central to discussions between initiative managers and community partners. Conservation outcomes on LSCAs often require land uses that are, almost by definition, less profitable for landowners. In other words, conservation involves an opportunity cost, as well as a direct cost, both of land management and administration and facilitation. Coordination of actions by landowners and investment in landscape restoration cannot be expected to occur spontaneously. Funding needs to be secured to cover costs on a continuing basis to achieve and maintain buy-in. This is a continuing and adaptive process that demands constant engagement and renewal.

At present, arrangements for large-scale conservation in the UK tend to be ad hoc and rely on funding from sources not designed for this purpose, especially agri-environment payments to landholders. This is a source of considerable administrative burden, instability, and uncertainty as to the capability and sustainability of initiatives to deliver over the long period of time required for conservation and ecological restoration. Funding for the facilitation and administration of the initiatives is obtained predominantly through projects that have to be invented to meet the demands of external sponsors. These may not align closely with the core mission of the initiative. They may then have to be reinvented in a different form to have a chance of continuation.

This pattern reflects the phenomenon of projectification in rural conservation (c.f. Sjöblom and Godenhjelm 2009, Sjöblom et al. 2013). State and charitable funders allocate funds competitively to projects with defined objectives for limited periods of time. The aim is to promote flexibility, accountability, and efficiency, and to direct a variety of actors to address defined objectives together (Sjöblom and Godenhjelm 2009). But these characteristics conflict with some of the key conservation requirements of the LSCA initiatives. Long-term continuity is required in order to deliver conservation outcomes. This continuity is disrupted by short project cycles, which work against the potential to build social capital and trust among the partners and the long-term changes in land management that are required to achieve significant ecological changes. Projectification also increases transaction costs - costs that are generally not considered by funders. Further, it is inconsistent with the more "open-ended" approach that is indicated by adaptive management (Hughes et al. 2011). Sponsored projects are generally required to set quantitative objectives and milestones from the start that can be demonstrated to have been achieved by the end. In contrast, an adaptive approach will shift its emphasis as information is gained through the implementation of the project.

Agri-environment contracts are a major source of funding for LSCAs (e.g., Utes and Matzdorf 2013, Hodge 2014) awarded to landscape partners. Agri-environment payments play a key role in securing biodiversity targeted land management interventions by landowners, operating within a broad regulatory framework designed as part of the Common Agricultural Policy (CAP) under other pressures and with different priorities (Hodge et al. 2015). Some, but not all, agri-environment agreements are targeted on local biodiversity objectives, which may or may not coincide with LSCA objectives. And, being based on relatively short voluntary 
agreements, they cannot be guaranteed to offer the particular incentives or continuity required for LSCAs. More generally, the availability of funds is dependent on agreement among EU member states on the way in which the CAP is funded into the future.

Agri-environment payments may be seen as one form of Payments for Ecosystem Services (PES) (Engel et al. 2008, Matzdorf et al. 2013). In future, it is possible that market-based mechanisms, such as PES, could become an important alternative source of funding, potentially through reform of the CAP (Plieninger et al. 2012) or through independent approaches. Partnerships might be able to diversify and secure their funding through the delivery of services to other beneficiaries. This implies that initiatives should develop a broader scope for their activities across other ecosystems services, such as habitat banking, flood protection, carbon storage, energy generation, or water purification (Defra 2014). This would require a more market-oriented approach that might challenge the approach that is taken toward ecological restoration.

Public conservation goals require an active and interventionist government to steer social and economic processes toward publicly desired outcomes and to stimulate market incentives that advance social interests. Neoliberalism may be seen as opening out the opportunities, but we see state re-engagement as a further stage that might be regarded as postneoliberal (Hodge and Adams 2014). To secure the public interest in nature, governments need to explore a wider set of policy instruments designed specifically for large-scale and long-term restoration efforts (e.g., conservation covenants [Hodge 2013]). The interplay of public and private investments and benefits will be critical. It will be particularly important to identify and support institutional arrangements that bring successful and sustainable outcomes, including funding arrangements that allow lower administrative costs. Ultimately, the success of large-scale conservation depends on finding institutional strategies that secure long-term conservation outcomes, thus ensuring that conservation gains are not reversed when money runs out, private owners change priorities, or land changes hands.

\section{CONCLUSIONS}

The survey of LSCA partnerships in England, Scotland, and Wales reveals the progress being made toward a novel approach to ecological restoration. At this stage, it is too early to know the extent to which the approach can deliver long-term ecological change. There are significant institutional challenges. Partnerships face challenges in envisioning, incentivizing, and sustaining initiatives to alter land management practices across a landscape scale. There is no single model suited to supporting the creation of LSCAs activity. The appropriate model will vary depending on local conservation requirements, as well as on local land tenure and farm practices, on the capabilities of civil society and local government, on potential sources of funding, and on government policy more generally. The neoliberal state aims to distance itself from direct engagement with land use decisions and hopes that biodiversity decline will be reversed through the largely spontaneous actions of private actors and civil society.

The achievements of LSCAs in the UK to date flow largely from the initiatives of conservation bodies supported by the resources that they have been able to command and through the somewhat opportunistic availability of agri-environment measures. This is unlikely to be sustainable. More research is needed to explore the diversity of approaches toward LSCA partnerships that are being adopted to identify the relative successes of different arrangements. But government policy also needs to support the development of institutional and funding arrangements that can combine long-term sustainability with public accountability.

Responses to this article can be read online at: http://www.ecologyandsociety.org/issues/responses. $\mathrm{php} / 8498$

\section{Acknowledgments:}

The research was funded by Natural England, Scottish Natural Heritage and the University of Cambridge Moran Fund. This paper was presented to the 9th European Conference on Ecological Restoration, Oulu, Finland, August 2014.

\section{LITERATURE CITED}

Adams, W. M. 2012. Private and networked: large conservation areas in Scotland. Ecos 33(3/4):124-133.

Adams, W. M., I. D. Hodge, and L. Sandbrook. 2014. New spaces for nature: the re-territorialisation of biodiversity conservation under neoliberalism in the UK. Transactions of the Institute of British Geographers 39:574-588. http://dx.doi.org/10.1111/ $\underline{\operatorname{tran} .12050}$

Armitage D. R., R. Plummer, F. Berkes, R. I. Arthur, A. T. Charles, I. J. Davidson-Hunt, A. P. Diduck, N. C. Doubleday, D. S. Johnson, M. Marschke, P. McConney, E. W. Pinkerton, and E. K. Wollenberg. 2009. Adaptive co-management for socialecological complexity. Frontiers in Ecology and the Environment 7:95-102. http://dx.doi.org/10.1890/070089

Armsworth, P. R., E. R. Larson, S. T. Jackson, D. F. Sax, P. Simonin, B. Blossey, N. Green, M. L. Klein, L. Lester, T. H. Ricketts, M. C. Runge, and M. R. Shaw. 2015. Are conservation organizations configured for effective adaptation to global change? Frontiers in Ecology and the Environment 13:163-169. http://dx.doi.org/10.1890/130352

Beever, E. A., B. J. Mattson, M. J. Germino, M. P. Van der Burg, J. B. Bradford, and M. W. Brunson. 2014. Successes and challenges from formation to implementation of eleven broad-extent conservation programs. Conservation Biology 28:302-314. http:// dx.doi.org/10.1111/cobi.12233

Benson, D., A. Jordan, H. Cook, and L. Smith. 2013. Collaborative environmental governance: Are watershed partnerships swimming or are they sinking? Land Use Policy 30:748-757. http://dx.doi.org/10.1016/j.landusepol.2012.05.016

Berkes, F. 2009. Evolution of co-management: role of knowledge generation, bridging organizations and social learning. Journal of Environmental Management 90:1692-1702. http://dx.doi.org/10.1016/ j.jenvman.2008.12.001

Browning, G., and R. Yanik. 2004. Wild Ennerdale: letting nature loose. $E \cos 25(3 / 4): 34-38$. 
Carlsson, L., and F. Berkes. 2005. Co-management: concepts and methodological implications. Journal of Environmental Management 75:65-76. http://dx.doi.org/10.1016/j.jenvman.2004.11.008

Convention on Biological Diversity (CBD). 2010. Aichi biodiversity targets. http://www.cbd.int/sp/targets

Cook, H., D. Benson, A. Inman, A. Jordan, and L. Smith. 2012. Catchment management groups in England and Wales: extent, roles and influences. Water and Environment Journal 26(1):47-55. http://dx.doi.org/10.1111/j.1747-6593.2011.00262.x

Crooks, K. R., and M. Sanjayan, editors. 2006. Connectivity Conservation. Cambridge University Press, Cambridge. http://dx. doi.org/10.1017/cbo9780511754821

Department for Environment, Food \& Rural Affairs (Defra). 2011. The natural choice: securing the value of nature. Natural Environment White Paper. https://www.gov.uk/government/ publications/the-natural-choice-securing-the-value-of-nature

Department for Environment, Food \& Rural Affairs (Defra). 2014. Defra Payments For Ecosystem Services (PES) pilot projects: review of key findings of Rounds 1 and 2, 2011-2013. https://www.gov.uk/government/publications/payments-for-ecosystemservices-review-of-pilot-projects-2011-to-2013

Eigenbrod, F., W. M. Adams, C. T. Hill, N. A. Macgregor, and P. E. Osborne. In press. Large-scale conservation in England, Scotland and Wales. Natural England, London, UK.

Ellis, S., C. R. Bulman, and N. A. D. Bourn. 2012. Landscapescale conservation for butterflies and moths-lessons from the UK. Butterfly Conservation, Wareham, Dorset, UK.

Emerson, K., T. Nabatchi, and S. Balogh. 2012. An integrative framework for collaborative governance. Journal of Public Administration Research and Theory 22:1-29. http://dx.doi. org/10.1093/jopart/mur011

Engel, S., S. Pagiola, and S. Wunder. 2008. Designing payments for environmental services in theory and practice: an overview of the issues. Ecological Economics 65:663-674. http://dx.doi. org/10.1016/j.ecolecon.2008.03.011

England Biodiversity Group. 2011. Think big: how and why landscape-scale conservation benefits wildlife, people and the wider economy. Report NE309. Natural England, London, UK.

Fitzsimons, J. A., and G. Wescott. 2005. History and attributes of selected Australian multi-tenure reserve networks. Australian Geographer 36:75-93. http://dx.doi.org/10.1080/00049180500050904

Fitzsimons, J. A., and G. Wescott. 2007. Perceptions and attitudes of land managers in multi-tenure reserve networks and the implications for conservation. Journal of Environmental Management 84:38-48. http://dx.doi.org/10.1016/j.jenvman.2006.05.009

Fitzsimons, J., I. Pulsford, and G. Wescott. 2013. Linking Australia's landscapes: lessons and opportunities for large-scale conservation networks. CSIRO Publishing, Melbourne, Victoria, Australia.

Heller, N. E., and E. S. Zavaleta. 2009. Biodiversity management in the face of climate change: a review of 22 years of recommendations. Biological Conservation 142:14-32. http://dx. doi.org/10.1016/j.biocon.2008.10.006
Hodge, I. 2013. Conservation covenants: a policy perspective. Conveyancer and Property Lawyer 6:490-500.

Hodge, I. 2014. European agri-environmental policy: the conservation and re-creation of cultural landscapes. Pages 583611 in In J. M. Duke and J. Wu, editors. The handbook of land economics. Oxford University Press, New York, USA.

Hodge, I. 2016. The governance of the countryside. Cambridge University Press. http://dx.doi.org/10.1017/cbo9780511980237

Hodge, I. D., and W. M. Adams. 2012. Neoliberalisation, rural land trusts and institutional blending. Geoforum 43(3):472-482. http://dx.doi.org/10.1016/j.geoforum.2011.11.007

Hodge, I. D., and W. M. Adams. 2014. Property institutions for rural land conservation: towards a post-neoliberal agenda. Journal of Rural Studies 36:453-462. http://dx.doi.org/10.1016/j. jrurstud.2014.05.004

Hodge, I., J. Hauck, and A. Bonn. 2015. The alignment of agricultural and nature conservation policies in the European Union. Conservation Biology 29:996-1005. http://dx.doi. org/10.1111/cobi.12531

Hughes, F. M. R., P. A. Stroh, W. M. Adams, K. Kirby, J. O. Mountford, and S. Warrington. 2011. Monitoring and evaluating large-scale, 'open-ended' habitat creation projects: a journey rather than a destination. Journal for Nature Conservation 19:245253. http://dx.doi.org/10.1016/j.jnc.2011.02.003

Lacher, I., and M. L. Wilkerson. 2013. Wildlife connectivity approaches and best practices in U.S. State Wildlife Action Plans. Conservation Biology 28(1):13-21. http://dx.doi.org/10.1111/ cobi.12204

Lammerant, J., R. Peters, M. Snethlage, B. Delbaere, I. Dickie, and G. Whiteley. 2013. Implementation of 2020 EU Biodiversity Strategy: priorities for the restoration of ecosystems and their services in the EU. Report to the European Commission. ARCADIS (in cooperation with ECNC and Eftec).

Lawton, J. H., P. N. M. Brotherton, V. K. Brown, C. Elphick, A. H. Fitter, J. Forshaw, R. W. Haddow, S. Hilborne, R. N. Leafe, G. M. Mace, M. P. Southgate, W. J. Sutherland, T. E. Tew, J. Varley, and G. R. Wynne. 2010. Making space for nature: a review of England's wildlife sites and ecological network. Report to Defra.

Lockie, S., and V. Higgins. 2007. Roll-out neoliberalism and hybrid practices of regulation in Australian agri-environmental governance. Journal of Rural Studies 23:1-11. http://dx.doi. org/10.1016/j.jrurstud.2006.09.011

Macgregor, N. A., W. M. Adams, C. T. Hill, F. Eigenbrod, and P. E. Osborne. 2012. Large-scale conservation in Great Britain: taking stock. Ecos 33(3/4):13-23.

Mansergh, I., D. Cheal, and J. A. Fitzsimons. 2008. Future landscapes in south-eastern Australia: the role of protected areas and biolinks in adaptation to climate change. Biodiversity 9(34):59-70. http://dx.doi.org/10.1080/14888386.2008.9712908

Matzdorf, B., C. Sattler, and S. Engel. 2013. Institutional frameworks and governance structures of PES schemes. Forest Policy and Economics 37:57-64. http://dx.doi.org/10.1016/j. forpol.2013.10.002 
McCarthy, J. 2005. Devolution in the woods: community forestry as hybrid neoliberalism. Environment and Planning A 37:9951014. http://dx.doi.org/10.1068/a36266

Metcalf, E. C., J. J. Mohr, L. Yung, P. Metcalf, and D. Craig. 2015. The role of trust in restoration success: public engagement and temporal and spatial scale in a complex social-ecological system. Restoration Ecology 23:315-324. http://dx.doi.org/10.1111/ $\underline{\text { rec. } 12188}$

Ostrom, E. 1990. Governing the commons: the evolution of institutions for collective action. Cambridge University Press. http://dx.doi.org/10.1017/CBO9780511807763

Ostrom, E. 2005. Understanding institutional diversity. Princeton University Press, Princeton, New Jersey, USA.

Pasquini, L., J. A. Fitzsimons, S. Cowell, K. Brandon, and G. Wescott. 2011. The establishment of large private nature reserves by conservation NGOs: key factors for successful implementation. Oryx 45:373-380. http://dx.doi.org/10.1017/S0030605310000876

Plieninger, T., C. Schleyer, H. Schaich, B. Ohnesorge, H. Gerdes, M. Hernández-Morcillo, and C. Bieling. 2012. Mainstreaming ecosystem services through reformed European agricultural policies. Conservation Letters 5:281-288. http://dx.doi.org/10.1111/ j.1755-263X.2012.00240.X

Radford, J. 2014. The role of private conservation in saving biodiversity in Australia. Ecological Management \& Restoration 15:2-3. http://dx.doi.org/10.1111/emr.12080

Rutherford, S. 2007. Green governmentality: insights and opportunities in the study of nature's rule. Progress in Human Geography 31: 291-307. http://dx.doi.org/10.1177/0309132507077080

Short, C. 2015. Micro-level crafting of institutions within integrated catchment management: early lessons of adaptive governance from a catchment-based approach case study in England. Environmental Science \& Policy 53:130-138. http://dx. doi.org/10.1016/j.envsci.2015.06.009

Sjöblom, S., and S. Godenhjelm. 2009. Project proliferation and governance-implications for environmental management. Journal of Environmental Policy \& Planning 11(3):169-185. http:// dx.doi.org/10.1080/15239080903033762

Sjöblom, S., K. Löfgren, and S. Godenhjelm. 2013. Projectified politics - temporary organisations in a public context. Scandinavian Journal of Public Administration 17(2):3-12.

Stolton, S., K. H. Redford, and N. Dudley. 2014. The futures of privately protected areas. IUCN Protected Areas Specialist Group, Gland, Switzerland.

Utes, S., and B. Matzdorf. 2013. Studies on agri-environmental measures: a survey of the literature. Environmental Management 51:251-266. http://dx.doi.org/10.1007/s00267-012-9959-6

Vos, C. C., P. Berry, P. Opdam, H. Baveco, B. Nijhof, J. O’Hanley, C. Bell, and H. Kuipers. 2008. Adapting landscapes to climate change: examples of climate-proof ecosystem networks and priority adaptation zones. Journal of Applied Ecology 45:17221731. http://dx.doi.org/10.1111/j.1365-2664.2008.01569.x 